\title{
Enteric nervous system, gut-brain connection and related neurodevelopmental disorders
}

\author{
Ece Alim $^{1,2,3}$ (D), I. Nadir Gülekon ${ }^{1}$ (D), Kerem Atalar ${ }^{4}$ (D), Meltem Bahçelioğlu ${ }^{1,2,3}$ (D) \\ ${ }^{1}$ Department of Anatomy, School of Medicine, Gazi University, Ankara, Turkey \\ ${ }^{2}$ Department of Neuroscience, Institute of Health Sciences, Gazi University, Ankara Turkey \\ ${ }^{3}$ Neuroscience and Neurotechnology Center of Excellence NÖROM, Gazi University, Ankara Turkey \\ ${ }^{4}$ Department of Anatomy, School of Medicine, Biilent Ecevit University, Ankara, Turkey
}

\begin{abstract}
The vagus nerve is the primary neural medium which enables gastrointestinal tract and brain communication. Hippocampus, a region of the brain commonly linked to memory function, is activated by vagus nerve-mediated gastrointestinal signals. Vagal afferent information is received by the medial solitary nucleus and is then transmitted via ascending neural pathways to different regions of the forebrain and hindbrain. Explanation of the exact mechanisms of microbiota and amygdala communication requires further research. By linking microbial activities to progressive structural and functional events in the brain in mice models and in humans, we can suggest that intestinal microbiota is an important contributor to neurodevelopment and neurodegeneration. Further researches revealing these relations may provide new approaches for understanding neurodegenerative, psychiatric and behavioral diseases.
\end{abstract}

Keywords: enteric nervous system; gut-brain connection; neurodegenerative diseases; vagus nerve

Anatomy 2020;14(1):61-67 @2020 Turkish Society of Anatomy and Clinical Anatomy (TSACA)

\section{Enteric Nervous System and Its Internal Structure}

When compared to other peripheral organs of the body, the gastrointestinal tract (GIT) differs from all of them. GIT has a comprehensive internal nervous system called enteric nervous system (ENS), which can control intestinal function, even if it is totally cut off from the central nervous system (CNS). ${ }^{[1]}$ The ENS provides unique innervation of the intestine and is the most neurochemically diverse part of the peripheral nervous system (PNS). ${ }^{[2]}$ The ENS was described by British physiologist John Newport Langley as one of the three autonomic nervous system parts: parasympathetic nervous system, enteric nervous system and sympathetic nervous system. ${ }^{[3]}$ More than 100 million efferent neurons that reach the intestines through the vagus nerve are present in human ENS. ${ }^{[4]}$ Unlike the rest of the PNS, the complexity of managing bowel behavior is a privilege that evolution provides to the ENS, which has led to the ability to manifest complementary neuronal activity and to control gastrointestinal behavior independently of the brain or spinal cord. ${ }^{[5-7]}$ The ENS has at least as many neurons as in the spinal cord but has more neurons than any other group of peripheral ganglia. Unique to PNS, the ENS is regulated in microcircuits with intrinsic primary afferent neurons (IPANs) and interneurons that are capable of initiating reflexes. The phenotypic diversity of enteric neurons is very wide and almost every class of neurotransmitters found in the CNS has been identified in the ENS. ${ }^{[6]}$ Although the ENS can work independently from the CNS, it normally does not; $\mathrm{CNS}$ affects the enteric system and the intestine also sends information to the brain. Indeed, $90 \%$ of the vagal fibers between the intestine and the brain are afferent, suggesting that the brain is more recipient than a giver in brainintestinal communication. ${ }^{[6,8]}$

ENS is located within the tubular digestive system walls, biliary system and pancreas. ENS has myenteric and submucosal plexuses, two ganglioned plexuses in the intestine, where almost all intrinsic nerve cells are present. ${ }^{[9]}$ The myenteric plexus is located between the outer longi- 
tudinal and circular muscle layers and runs from the esophagus to the rectum along the full length of the digestive tract. The submucosal plexus is found only in the large and small intestines. ${ }^{[10]}$

The enteric motor neuron has five broad types and many subtypes; excitatory neurons that excite intestinal muscles, inhibitory neurons that inhibit intestinal muscles, vasodilator/secretomotor neurons, non-vasodilator secretomotor neurons, and neurons that innervate the enteroendocrine cells. ${ }^{[1]]}$ In the guinea pig's small intestine, one type of ascending as well as three types of descending interneurons have been identified. Neurons that ascend, which have enkephalin/calretinin/ChAT (ENK/calretinin/ChAT) chemical code, are cholinergic and form chains extending across the intestine, such as descending neurons. ${ }^{[12]}$ The three descending interneuron species that the intestines have are called by the following names and chemical codes: nitric oxide synthase/choline acetyltransferase/vasoactive intestinal peptide \pm gammaaminobutyric acid \pm bombesin \pm neuropeptide $\mathrm{Y}$ (NOS/ $\mathrm{ChAT} / \mathrm{VIP} \pm \mathrm{GABA} \pm \mathrm{BN} \pm \mathrm{NPY})$, choline acetyltransferase/ 5-hydroxytryptamine (ChAT/5-HT) and choline acetyltransferase/somatostatin (ChAT/SOM). With the investigation of all these neurons' connections, the hypothesis that ChAT/NOS/VIP neurons involved in local mobility reflexes were related to the transmission of migrating myoelectric complexes (MMCs) of ChAT/SOM neurons. It was found that neurons were directly involved in secretomotor reflexes but indirectly in mobility reflexes in the small intestine and ChAT/5-HT ${ }^{[1,13]}$ ChAT/SOM neurons have distinctive morphology with branching filament dendritic cell bodies. In the distal colon, filamentous neurons with anal axons are not present but they are present in the colon. ${ }^{[14-16]}$

Many studies have noted that reflexes occur in the isolated intestine, even after the cut-off of the extrinsic nerves feeding the intestines and after a certain period of time for the ends to degenerate. This indicates the presence of IPANs (sensory neurons) in the intestine. ${ }^{[17,18]}$

Intestinal secretomotor neurons of two types have been identified that are cholinergic and non-cholinergic, and also the release of IPANs in the mucosa from the ends of these neurons, indicates that these cells may have secretomotor effects. ${ }^{[11]}$ It has been shown that non-cholinergic neurons use VIP or a related peptide as their main transmitter and mediate the majority of the local reflex response. The point of innervation of $\mathrm{ACh} /$ calretin neurons and the secretory glands is the mucosal base where the former have collaterals against submucosal arterioles but ACh/NPY neurons don't supply innervation to the arterioles. ${ }^{[1]]}$

\section{Gut-Brain and Vagus Nerve}

The vagus nerve serves as the first neural communication mediator between the brain and the gastrointestinal (GI) system. The vagus nerve transmits energy state signals through the vagal afferent (sensory) nerves from the intestine to the brain. There are separate afferent fibers innervating GI organs to determine intestinal nutrient content or stomach volume. ${ }^{[19-21]}$ Afferent fibers mentioned include cell bodies inside the nodose ganglia synapsing with the CNS. The medial nucleus of the solitary tract (mNTS) in the caudal brain stem acquires vagal afferent/sensory information in the brain and the information is then transmitted via ascending neural pathways to the various hindbrain and forebrain regions. ${ }^{[2]}$ Vagal-mediated signaling from the GI organs is first received in the mNTS area of the brain. ${ }^{[23]}$ GI-mediated signals, such as direct vagus nerve stimulation, mechanical tension in the stomach, and intestinal infusion, activate neurons in a region of the brain that is classically affiliated with memory control, feeding behavior, and learning; the hippocampus (HPC) ${ }^{[22,24-27]}$ Studies of Clark et al. ${ }^{[28-30]}$ have shown that unilateral cervical vagus nerve stimulation and stimulated vagal afferents by inactivation of the vagal efferents, improve inhibition-avoidance retention memory in rats, while in humans, vagus nerve stimulation increases retention in recognition memory as stimulation occurs upon learning.

The vagus nerve promotes neurotrophic and neurogenic signaling. The endogenous relevance of vagal signaling, particularly the vagal afferent pathways of the innervated intestines, abnormal and cognitive control is not well understood. The neural pathways that enable transmission of vagal mediated energy-state signals between hippocampal neurons and the GI pathway have not totally clarified. Furthermore, the neural pathways which cater for the transmission of vagal mediated energy-state signals between the GI pathway and hippocampal neurons are not completely understood. MNTS, where sensory inputs from the digestive system synapse here, sends projections to several brainstem and forebrain regions, but not directly to the HPC. ${ }^{[31-33]}$ This shows that communication between mNTS and HPC is made through multiple nerve projection pathways. The potential brain region reserve location that binds $\mathrm{mNTS}$ to the ventral CA1 HPC (one of the subregions of the HPC) was defined as the locus coeruleus (LC) and the medial septum (MS) ${ }^{[31]}$ In the world of gut-brain connection, HPC is a new player. GI signal with in-meal saturation signals (eg, gastric bloating, intestinal food infusion) activates cerebral blood flow $(\mathrm{CBF})$ in hippocampal neurons in rodents. ${ }^{[2,34]}$ 
In addition, HPC blood flow is strongly actuated after gastric vagal nerve stimulation in people suffering from obesity. ${ }^{[27]}$

Suarez et al. ${ }^{[2]}$ noted that the gastrointestinal derived vagal sensory signaling supports hippocampus-dependent memory function by way of brainstem-septal nerve pathway, in this way initializing a previously unbeknown act for the axis of the brain-gut in memory control. Other studies have shown that vagal nerve stimulation, mimicking afferent signaling from the intestine, has been successfully used to treat depression, and also increases memory as well as learning in both humans and animals. ${ }^{[3,36]}$ Potentially, luminal microbiota can affect behavior, mood, and brain development via signals transmitting by the vagus nerve..$^{[0,37-39]}$

The amygdala is a small, almond-like structure and is considered one of the most important parts in the limbic system and has a vast record of scientific research in emotion processing with its role in behavior modulation. ${ }^{[0,41]}$ Because it is located centrally in the temporal lobe, the amygdala complex is highly joined to multiple brain regions. Amygdala receives sensory input from thalamus and cortical regions, as well as various other sites in the limbic system, including hippocampus and the prefrontal cortex. $^{[42]}$

There are noradrenergic projections extending directly and indirectly from NTS to amygdala. ${ }^{[43]}$ Thus, visceral information received by the vagus nerve may ultimately affect amygdala activity. In fact, vagus nerve stimulation has been shown to stimulate norepinephrine release in the amygdala,${ }^{[4]}$ increasing behavioral outcomes in preclinical fear extinction models and clinical trials of major depressive disorder, and regulating connections to the amygdala prefrontal cortex. ${ }^{[4,46]}$ In contrast, the interruption of vagal communication in the subdiaphragmatic disruption of the vagus nerve has been shown to reduce fear depletion but to reduce anxiety-like behavior in rats. ${ }^{[4]}$

Numerous neurodevelopmental complications are also linked to abnormalities in the amygdala. Changes in amygdala efficacy, volume (properties affected by the intestinal microbiota) ${ }^{[48-51]}$ and/or connectivity have been reported in individuals diagnosed with attention deficit hyperactivity disorder, ${ }^{[52]}$ schizophrenia, ${ }^{[3,54]}$ and autism spectrum disorders (ASD). ${ }^{[5,56]}$

\section{Link between the Gut Microbiota-Brain and Neurodevelopmental Disorders}

In humans, the gastrointestinal tract is collectively colonized by trillions of microorganisms called intestinal microbiota. This gut microbiota regulate host physiology in many aspects, including the maturation and function of the immune system. ${ }^{[57-59]}$ Furthermore, increasing evidence suggests that intestinal microbiota have effects on brain development, function and regulation of behavior. ${ }^{[37,60,61]}$

Brain development in mammals is a complex process that lasts until adolescence and in humans lasts until early adulthood. In addition, the brain development process involves the passage of cells over longer distances to create specific circuits underlying behavior, as well as the migration of cells to extraordinary, large-scale long distances during certain fetal development. ${ }^{[62,63]}$ The biggest portal in the molecular universe is the intestine hence it has been shown that various dietary ingredients interact directly with the brain development and trigger functional changes in the grown-up brain. ${ }^{[64,65]}$ Recent research has found evidence that the intestinal microbiota has long-term effects on health, such as leading and easing developmental processes in the brain.

The mammalian microbiome consists of a unique combination of many different microorganisms (i.e. bacteria, fungi, archaea, and viruses) in the body. There are many pieces of research showing the effect of the intestinal microbiome on CNS function, but most of these researches are preclinic, rather than human investigations. ${ }^{[1,66]}$ These include diet management, interventions that bolster the growth of beneficial bacteria (like prebiotics), administration of specific bacterial strains (like probiotics), antibiotic treatments, germ-free mice (microbiota deficient), fecal microbiota transplantation and C-section. ${ }^{[67]}$ Recent reports of studies on mice models show that disruption of the microbiome will contribute to the understanding of the pathology of various neurological diseases. According to evidence from rodent models, there is a direct link between intestinal microbiota, stress and anxiety ${ }^{[68]}$ Research on human and animal models has linked intestinal bacteria with the function and development of the immune system. Microbiota includes all types of immune cells, and specific microbes that increase or ameliorate immunological disorders like asthma, inflammatory bowel disease and type 1 diabetes. ${ }^{[6]]}$ There are many animal models research based on the potential role of the microbiome in neuropsychiatric disorders like depression, anxiety, ${ }^{[68]}$ autism spectrum disorder ${ }^{[70]}$ schizophrenia, ${ }^{[7]}$ Parkinson's disease, and Alzheimer's disease. $^{[72]}$

Increasing evidence indicates bi-directional nature of communication between intestinal microbial populations and brain. ${ }^{[73-76]}$ De Palma et al..$^{[77]}$ used a maternal separation model in mice and showed deep differences in intes- 
tinal microbiota in response to early life stress resulting in an anxiety-like phenotype. It has also been reported that intestinal bacteria have a reciprocal effect where certain bacteria or whole microbial populations have an effect on host stress and depression-like behavior. ${ }^{[78-80]}$ It is not yet clear whether these examples are directly driven by an intestinal-brain interaction or mediated by other physiological factors caused by the disease state. But these reports and others illustrate potential interactive relations between the gastrointestinal tract microbiome and the brain.

Evidences from studies in rodent animal models show that intestinal microbiome plays a role in depressive behavior. ${ }^{[81-83]}$ Approximately $20 \%$ of patients with gastrointestinal symptoms have been reported to be associated with depression. ${ }^{[84]}$ According to a hypothesis, depression or subsets of this disorder are the result of a microglial disorder, since the presence of depression commonly leads to either intense inflammatory episodes in the brain or a descend in microglial function. ${ }^{[85]}$ According to latest findings on the role of the microbiota in microglia maturation and activation, it is not difficult to predict that microbiota can trigger depression by affecting microglial maturation and activation. ${ }^{[86,87]}$ In a study on depression, reduced bacterial richness and diversity were addressed and it was reported that depression-like phenotypes could be transmitted to rats by fecal transplantation. ${ }^{[8]}$ More recently, studies on mice and humans have indicated that microbiota has an active role in guiding depression-like behavior and suggests potential new ways of therapeutic development.

In this review, in the light of general information about the enteric nervous system and its internal structure, we evaluate the relationship between microbiota and brain in human as well as animal models through many studies with gut and vagus nerve connections. The vagus nerve is the primary neuron that enables the gastrointestinal tract-brain communication. Vagus nerve mediated gastrointestinal signals activate the hippocampus. Explanation of the exact mechanism concerning microbiota and amygdala communication requires further research. By linking microbial activities to progressive structural and functional events in the brain in mice models and in humans, we can suggest that intestinal microbiota is an important contributor to neurodevelopment and neurodegeneration. Further researches revealing these relations may provide new approaches for understanding neurodegenerative, psychiatric and behavioral diseases.

\section{Author Contributions}

EA: designing the review and writing text, EA and KA: literature search, EA, KA, MB and ING: writing text, final check of the manuscript.

\section{References}

1. Furness JB. The enteric nervous system and neurogastroenterology. Nat Rev Gastroenterol Hepatol 2012;9:286-94.

2. Lake JI, Heuckeroth RO. Enteric nervous system development: migration, differentiation, and disease. Am J Physiol Liver Physiol 2013;305:G1-G24.

3. Langley J. Langley, JN. The autonomic nervous system, Part 1 [1921]. Cornell Univ. Library; Digital Collections 2010, p. 2-3.

4. Furness JB. The enteric nervous system, Scholarpedia 2006;2:4064.

5. Gershon MD. The enteric nervous system: a second brain. Hosp Pract (1995) 1999 15;34:31-2

6. Furness JB, Callaghan BP, Rivera LR, Cho H-J. The enteric nervous system and gastrointestinal innervation: integrated local and central control. Adv Exp Med Biol 2014;817:39-71.

7. Gershon MD. Developmental determinants of the independence and complexity of the enteric nervous system. Trends Neurosci 2010;33:446-56.

8. Forsythe P, Bienenstock J, Kunze WA. Vagal pathways for microbiome-brain-gut axis communication. Adv Exp Med Biol 2014;817: 115-33.

9. Furness JB, Costa M. Types of nerves in the enteric nervous system. Neuroscience 1980;5:1-20.

10. Furness JB. Types of neurons in the enteric nervous system. J Auton Nerv Syst 2000;81:87-96.

11. Furness JB, Clerc N, Gola M, Kunze WAA, Fletcher EL. Identification of component neurons and organisation of enteric nerve circuits. In: Krammer HJ, Singer MV, editors. Neurogastroenterology - From the basics to the clinics. Dordrecht: Kluwer Academic; 2000. p. 134-47.

12. Kunze WA, Furness JB. The enteric nervous system and regulation of intestinal motility. Annu Rev Physiol 1999;61:117-142.

13. Pompolo S, Furness JB. Ultrastructure and synaptic relationships of calbindin-reactive, Dogiel type II neurons, in myenteric ganglia of guinea-pig small intestine. J Neurocytol 1988;17:771-782.

14. Lomax AE, Sharkey KA, Bertrand PP, Low AM, Bornstein JC, Furness JB. Correlation of morphology, electrophysiology and chemistry of neurons in the myenteric plexus of the guinea-pig distal colon. J Auton Nerv Syst 1999;76:45-61.

15. Song Z-M, Brookes SJ, Ramsay G, Costa M. Characterization of myenteric interneurons with somatostatin immunoreactivity in the guinea-pig small intestine. Neuroscience 1997;80:907-23.

16. Portbury AL, Pompolo S, Furness JB, Stebbing MJ, Kunze WA, Bornstein JC, Hughes S. Cholinergic, somatostatin-immunoreactive interneurons in the guinea pig intestine: morphology, ultrastructure, connections and projections. J Anat 1995;187:303-21.

17. Furness JB, Johnson PJ, Pompolo S, Bornstein JC. Evidence that enteric motility reflexes can be initiated through entirely intrinsic mechanisms in the guinea-pig small intestine. Neurogastroenterol Motil 1995;7:89-96. 
18. Crema A, Frigo Gm, Lecchini S. A pharmacological analysis of the peristaltic reflex in the isolated colon of the guinea-pig or cat. Br J Pharmacol 1970;39:334-45.

19. Powley TL, Phillips RJ. Gastric satiation is volumetric, intestinal satiation is nutritive. Physiol Behav 2004;82:69-74.

20. Brookes SJH, Spencer NJ, Costa M, Zagorodnyuk VP. Extrinsic primary afferent signalling in the gut. Nat Rev Gastroenterol Hepatol 2013;10:286-96.

21. Williams EK, Chang RB, Strochlic DE, Umans BD, Lowell BB, Liberles SD. Sensory neurons that detect stretch and nutrients in the digestive system. Cell 2016;166:209-21.

22. Suarez AN, Hsu TM, Liu CM, Noble EE, Cortella AM, Nakamoto EM, Hahn JD, Lartigue G, Kanoski SE. Gut vagal sensory signaling regulates hippocampus function through multi-order pathways. Nat Commun 2018;9:2181.

23. Grill HJ, Hayes MR. Hindbrain neurons as an essential hub in the neuroanatomically distributed control of energy balance. Cell Metab 2012;16:296-309.

24. Min DK, Tuor UI, Chelikani PK. Gastric distention induced functional magnetic resonance signal changes in the rodent brain. Neuroscience 2011;179:151-8.

25. Kanoski SE, Grill HJ. Hippocampus contributions to food intake control: mnemonic, neuroanatomical, and endocrine mechanisms. Biol Psychiatry 2017;81:748-56.

26. Min DK, Tuor UI, Koopmans HS, Chelikani PK. Changes in differential functional magnetic resonance signals in the rodent brain elicited by mixed-nutrient or protein-enriched meals. Gastroenterology 2011;141:1832-41.

27. Wang G-J, Yang J, Volkow ND, Telang F, Ma Y, Zhu W, Wong CT, Tomasi D, Thanos PK, Fowler JS. Gastric stimulation in obese subjects activates the hippocampus and other regions involved in brain reward circuitry. Proc Natl Acad Sci U S A 2006;103:15641-5.

28. Clark KB, Krahl SE, Smith DC, Jensen RA. Post-training unilateral vagal stimulation enhances retention performance in the rat. Neurobiol Learn Mem 1995;63:213-6.

29. Clark KB, Naritoku DK, Smith DC, Browning RA, Jensen RA. Enhanced recognition memory following vagus nerve stimulation in human subjects. Nat Neurosci 1999;2:94-8.

30. Clark KB, Smith DC, Hassert DL, Browning RA, Naritoku DK, Jensen RA. Posttraining electrical stimulation of vagal afferents with concomitant vagal efferent inactivation enhances memory storage processes in the rat. Neurobiol Learn Mem 1998;70:364-73.

31. Castle M, Comoli E, Loewy AD. Autonomic brainstem nuclei are linked to the hippocampus. Neuroscience 2005;134:657-69.

32. Rinaman L. Ascending projections from the caudal visceral nucleus of the solitary tract to brain regions involved in food intake and energy expenditure. Brain Res 2010;1350:18-34.

33. Mello-Carpes PB, Izquierdo I. The nucleus of the solitary tract $\rightarrow$ nucleus paragigantocellularis $\rightarrow$ locus coeruleus $\rightarrow$ CA1 region of dorsal hippocampus pathway is important for consolidation of object recognition memory. Neurobiol Learn Mem 2013;100:56-63.

34. Xu L, Sun X, Lu J, Tang M, Chen JDZ. Effects of gastric electric stimulation on gastric distention responsive neurons and expressions of CCK in rodent hippocampus. Obesity (Silver Spring) 2008;16: 951-7.

35. Rush AJ, George MS, Sackeim HA, Marangell LB, Husain MM, Giller C, Nahas Z, Haines S, Simpson Jr RK, Goodman R. Vagus nerve stimulation (VNS) for treatment-resistant depressions: a multicenter study. Biol Psychiatry 2000;47:276-86.

36. George MS, Sackeim HA, Rush AJ, Marangell LB, Nahas Z, Husain MM, Lisanby S, Burt T, Goldman J, Ballenger JC. Vagus nerve stimulation: a new tool for brain research and therapy. Biol Psychiatry 2000;47:287-95.

37. Sampson TR, Mazmanian SK. Control of brain development, function, and behavior by the microbiome. Cell Host Microbe 2015;17: 565-76.

38. Yano JM, Yu K, Donaldson GP, Shastri GG, Ann P, Ma L, Nagler CR, Ismagilov RF, Mazmanian SK, Hsiao EY. Indigenous bacteria from the gut microbiota regulate host serotonin biosynthesis. Cell 2015;161:264-76.

39. Mayer EA, Knight R, Mazmanian SK, Cryan JF, Tillisch K. Gut microbes and the brain: paradigm shift in neuroscience. J Neurosci 2014;34:15490-6.

40. Davis M, Walker DL, Miles L, Grillon C. Phasic vs sustained fear in rats and humans: role of the extended amygdala in fear vs anxiety. Neuropsychopharmacology 2010;35:105-35.

41. LeDoux J. The emotional brain, fear, and the amygdala. Cell Mol Neurobiol 2003;23:727-38.

42. Knapska E, Radwanska K, Werka T, Kaczmarek L. Functional internal complexity of amygdala: focus on gene activity mapping after behavioral training and drugs of abuse. Physiol Rev 2007;87:111373

43. Berntson GG, Sarter M, Cacioppo JT. Ascending visceral regulation of cortical affective information processing. Eur J Neurosci 2003;18; 2103-9.

44. Hassert DL, Miyashita T, Williams CL. The effects of peripheral vagal nerve stimulation at a memory-modulating intensity on norepinephrine output in the basolateral amygdala. Behav Neurosci 2004; 118:79-88.

45. Peña DF, Childs JE, Willett S, Vital A, McIntyre CK, Kroener S. Vagus nerve stimulation enhances extinction of conditioned fear and modulates plasticity in the pathway from the ventromedial prefrontal cortex to the amygdala. Front Behav Neurosci 2014;8:327.

46. Liu J, Fang J, Wang Z, Rong P, Hong Y, Fan Y, Wang X, Park J, Jin Y, Liu C, Zhu B, Kong J. Transcutaneous vagus nerve stimulation modulates amygdala functional connectivity in patients with depression. J Affect Disord 2016;205:319-26.

47. Klarer M, Arnold M, Günther L, Winter C, Langhans W, Meyer U. Gut vagal afferents differentially modulate innate anxiety and learned fear. J Neurosci 2014;34:7067-76.

48. Luczynski P, Whelan SO, O'Sullivan C, larke G, Shanahan F, Dinan TG, Cryan JF. Adult microbiota-deficient mice have distinct dendritic morphological changes: differential effects in the amygdala and hippocampus. Eur J Neurosci 2016;44:2654-66.

49. Tillisch K, Labus J, Kilpatrick L, Jiang Z, Stains J, Ebrat B, Guyonnet D, Legrain-Raspaud S, Trotin B, Naliboff B, Mayer EA. Consumption of fermented milk product with probiotic modulates brain activity. Gastroenterology 2013;144:1394-401.

50. Stilling RM, Ryan FJ, Hoban AE, Shanahan F, Clarke G, Claesson MJ, Dinan TG, Cryan JF. Microbes \& neurodevelopment - absence of microbiota during early life increases activity-related transcriptional pathways in the amygdala. Brain Behav Immun 2015;50:20920. 
51. Hoban AE, Stilling RM, M. Moloney G, Moloney RD, Shanahan F, Dinan TG, Cryan JF, Clarke G. Microbial regulation of microRNA expression in the amygdala and prefrontal cortex. Microbiome 2017; 5:102.

52. Hulvershorn LA, Mennes M, Castellanos FX, Di Martino A, Milham MP, Hummer TA, Roy AK. Abnormal amygdala functional connectivity associated with emotional lability in children with attention-deficit/hyperactivity disorder. J Am Acad Child Adolesc Psychiatry 2014;53:351-61.

53. Liu H, Tang Y, Womer F, Fan G, Lu T, Driesen N, Ren L, Wang Y, He Y, Blumberg HP, Xu K, Wang F. Differentiating patterns of amygdala-frontal functional connectivity in schizophrenia and bipolar disorder. Schizophr Bull 2014;40:469-77.

54. Lawrie SM, Whalley HC, Job DE, Johnstone EC. Structural and functional abnormalities of the amygdala in schizophrenia. Ann N Y Acad Sci 2003;985:445-60.

55. Amaral DG, Schumann CM, Nordahl CW. Neuroanatomy of autism. Trends Neurosci 2008;31:137-45.

56. Kleinhans NM, Reiter MA, Neuhaus E, Pauley G, Martin N, Dager S, Estes A. Subregional differences in intrinsic amygdala hyperconnectivity and hypoconnectivity in autism spectrum disorder. Autism Res 2016;9:760-72.

57. Belkaid Y, Hand TW. Role of the microbiota in immunity and inflammation. Cell 2014;157:121-41.

58. Honda K, Littman DR. The microbiota in adaptive immune homeostasis and disease. Nature 2016;535:75-84.

59. Rooks MG, Garrett WS. Gut microbiota, metabolites and host immunity. Nat Rev Immunol 2016;16:341-52.

60. Collins SM, Surette M, Bercik P. The interplay between the intestinal microbiota and the brain. Nat Rev Microbiol 2012;10:735-42.

61. Cryan JF, Dinan TG. Mind-altering microorganisms: the impact of the gut microbiota on brain and behaviour. Nat Rev Neurosci 2012; 13:701-12.

62. Geschwind DH, Rakic P. Cortical evolution: judge the brain by its cover. Neuron 2013;80:633-47.

63. Marín O, Rubenstein JLR. Cell migration in the forebrain. Annu Rev Neurosci 2003;26:441-83.

64. Chang C-Y, Ke D-S, Chen J-Y. Essential fatty acids and human brain. Acta Neurol Taiwan 2009;18:231-41.

65. Zeisel SH. Nutritional importance of choline for brain development. J Am Coll Nutr 2004;23:621S-6S.

66. Borre YE, O'Keeffe GW, Clarke G, Stanton C, Dinan TG, Cryan JF. Microbiota and neurodevelopmental windows: implications for brain disorders. Trends Mol Med 2014;20:509-18.

67. Luczynski P, McVey Neufeld K-A, Oriach CS, Clarke G, Dinan TG, Cryan JF. Growing up in a bubble: using germ-free animals to assess the influence of the gut microbiota on brain and behavior. Int J Neuropsychopharmacol 2016;19:pyw020.

68. Foster JA, McVey Neufeld K-A. Gut-brain axis: how the microbiome influences anxiety and depression. Trends Neurosci 2013;36: 305-12.

69. Round JL, Mazmanian SK. The gut microbiota shapes intestinal immune responses during health and disease. Nat Rev Immunol 2009;9:313-23.

70. Krajmalnik-Brown R, Lozupone C, Kang D-W, Adams JB. Gut bacteria in children with autism spectrum disorders: challenges and promise of studying how a complex community influences a complex disease. Microb Ecol Health Dis 2015;26:26914.

71. Severance EG, Yolken RH, Eaton WW. Autoimmune diseases, gastrointestinal disorders and the microbiome in schizophrenia: more than a gut feeling. Schizophr Res 2016;176:23-35.

72. Keshavarzian A, Green SJ, Engen PA, Voigt RM, Naqib A, Forsyth CB, Mutlu E, Shannon KM. Colonic bacterial composition in Parkinson's disease. Mov Disord 2015;30:1351-60.

73. Bailey MT, Dowd SE, Galley JD, Hufnagle AR, Allen RG, Lyte M. Exposure to a social stressor alters the structure of the intestinal microbiota: implications for stressor-induced immunomodulation. Brain Behav Immun 2011;25:397-407.

74. Carabotti M, Scirocco A, Maselli MA, Severi C. The gut-brain axis: interactions between enteric microbiota, central and enteric nervous systems. Ann Gastroenterol 2015;28:203-9.

75. Moussaoui N, Braniste V, Ait-Belgnaoui A, Gabanou M, Sekkal S, Olier M, Theodorou V, Martin PGP, Houdeau E. Changes in intestinal glucocorticoid sensitivity in early life shape the risk of epithelial barrier defect in maternal-deprived rats. PLoS One 2014;9:e88382.

76. Park AJ, Collins J, Blennerhassett PA, Ghia JE, Bercik P, Collins SM. Altered colonic function and microbiota profile in a mouse model of chronic depression. Neurogastroenterol Motil 2013;25: 733-e575.

77. De Palma G, Blennerhassett P, Lu J, Deng Y, Park AJ, Green W, Denou E, Silva MA, Santacruz A, Sanz Y, Surette MG, Verdu EF, Collins SM, Bercik P. Microbiota and host determinants of behavioural phenotype in maternally separated mice. Nat Commun 2015; 6:7735.

78. Bercik P, Denou E, Collins J, Jackson W, Lu J, Jury J, Deng Y, Blennerhassett P, Marci J, McCoy KD, Verdu EF, Collins SM. The intestinal microbiota affect central levels of brain-derived neurotropic factor and behavior in mice. Gastroenterology 2011; 141:599-609.

79. Gacias M, Gaspari S, Santos P-MG,Tamburini S, Andrade M, Zhang F, Shen N, Tolstikov V, Kiebish MA, Dupree JL, Zachariou V, Clemente JC, Casaccia P. Microbiota-driven transcriptional changes in prefrontal cortex override genetic differences in social behavior. Elife 2016;5:e13442.

80. Sudo N, Chida Y, Aiba Y, Sonoda JS, Oyama N, Yu X-N, Kubo C. Postnatal microbial colonization programs the hypothalamic-pituitary-adrenal system for stress response in mice. J Physiol 2004;558: 263-75.

81. Bravo JA, Forsythe P, Chew MV, Escaravage E, Savignac HM, Dinan TG, Bienenstock J, Cryan JF. Ingestion of Lactobacillus strain regulates emotional behavior and central GABA receptor expression in a mouse via the vagus nerve. Proc Natl Acad Sci USA 2011;108:16050-5.

82. Desbonnet L, Garrett L, Clarke G, Kiely B, Cryan JF, Dinan TG. Effects of the probiotic Bifidobacterium infantis in the maternal separation model of depression. Neuroscience 2010;170:1179-88.

83. Mello BSF, Monte AS, McIntyre RS, Soczynska JK, Custódio CS, Cordeiro RC, Chaves JH, Vasconcelos SM, Nobre HV Jr, Florenço de Sousa FC, Hyphantis TN, Carvalho AF, Macêdo DS. Effects of doxycycline on depressive-like behavior in mice after lipopolysaccharide (LPS) administration. J Psychiatr Res 2013;47:1521-9.

84. Mussell M, Kroenke K, Spitzer RL, Williams JBW, Herzog W, Löwe B. Gastrointestinal symptoms in primary care: prevalence and association with depression and anxiety. J Psychosom Res 2008;64: 605-12. 
85. Yirmiya R, Rimmerman N, Reshef R. Depression as a microglial disease. Trends Neurosci 2015;38:637-58.

86. Erny D, Hrabû de Angelis AL, Jaitin D, Wieghofer P, Staszewski O, David E, Keren-Shaul H, Mahlakoiv T, Jakobshagen K, Buch T, Schwierzeck V, Utermöhlen O, Chun E, Garrett WS, McCoy KD, Diefenbach A, Staeheli P, Stecher B, Amit I, Prinz M. Host microbiota constantly control maturation and function of microglia in the CNS. Nat Neurosci 2015;18:965-77.

87. Matcovitch-Natan O, Winter DR, Giladi A, Aguilar SV, Spinrad A, Sarrazin S, Ben-Yehuda H, David E, González FZ, Perrin P, Keren-

ORCID ID:

E. Alim 0000-0002-4686-0677; I. N. Gülekon 0000-0002-9352-5118; K. Atalar 0000-0003-1239-1144; M. Bahçelioğlu 0000-0001-5279-3450

deomed.

Shaul H, Gury M, Lara-Astaiso D, Thaiss CA, Cohen M, Halpern KB, Baruch K, Deczkowska A, Lorenzo-Vivas E, Itzkovitz S, Elinav E, Sieweke MH, Schwartz M, Amit I. Microglia development follows a stepwise program to regulate brain homeostasis. Science 2016;353:aad8670.

88. Kelly JR, Borre Y, O’ Brien C, Patterson E, El Aidy S, Deane J, Kennedy PJ, Beers S, Scott K, Moloney G, Hoban AE, Scott L, Fitzgerald P, Ross P, Stanton C, Clarke G, Cryan JF, Dinan TG. Transferring the blues: depression-associated gut microbiota induces neurobehavioural changes in the rat. J Psychiatr Res 2016; 82:109-18.

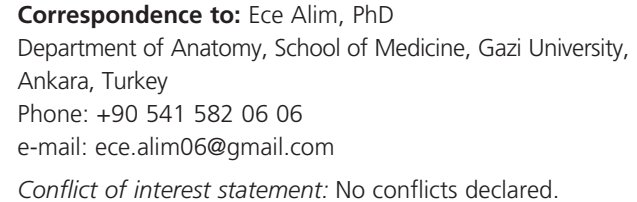

This is an open access article distributed under the terms of the Creative Commons Attribution-NonCommercial-NoDerivs 3.0 Unported (CC BY-NCND3.0) Licence (http://creativecommons.org/licenses/by-nc-nd/3.0/) which permits unrestricted noncommercial use, distribution, and reproduction in any medium, provided the original work is properly cited. Please cite this article as: Alim E, Gülekon IN, Atalar K, Bahçelioğlu M. Enteric nervous system, gutbrain connection and related neurodevelopmental disorders. Anatomy 2020;14(1):61-67. 